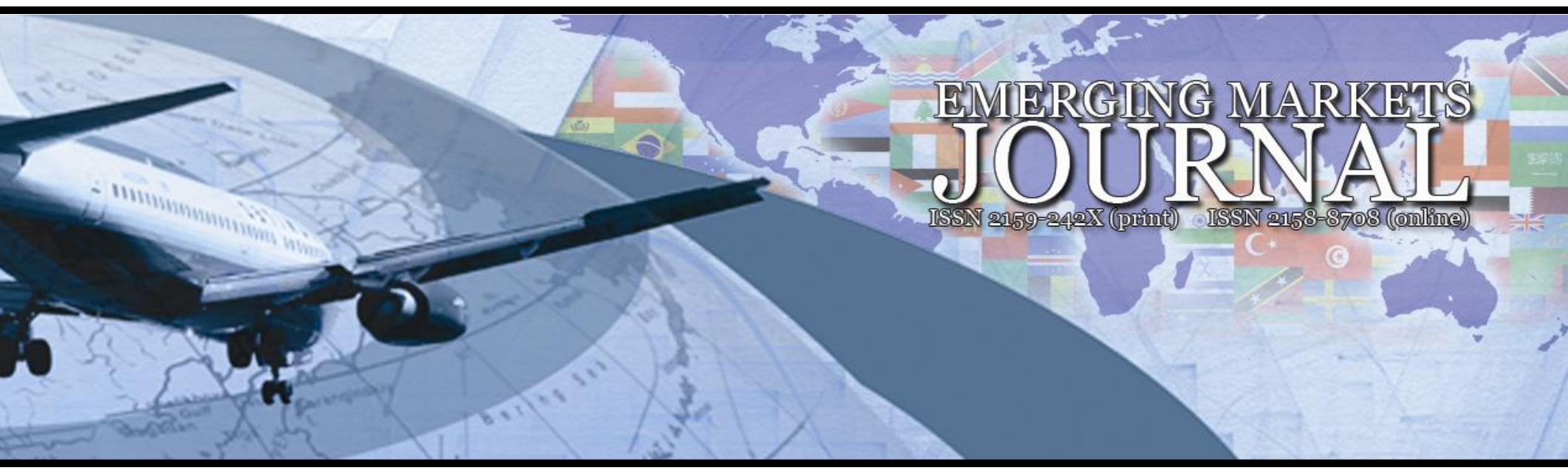

\title{
The Relationship between the Budget Deficit and Current Account Deficit in Turkey
}

\section{Seyfettin Erdoğan}

İstanbul Medeniyet University | e-mail: seyfettin.erdogan@medeniyet.edu.tr

\section{Durmuş Çağrı Yıldırım}

Recep Tayyip Erdoğan University | e-mail: cyildirim81@gmail.com

Volume 3 No 3 (2014) ｜ ISSN 2158-8708 (online) | DOI 10.5195/emaj.2014.52 | http://emaj.pitt.edu |

\section{Abstract}

One of the most debated topics in Economics literature is the relation between budget deficit and current account deficit. The data obtained from the presence of this kind of relation is leading for policy makers in terms of determining the quality of the policy to be preferred and the economic policy to be pursued. In this study, the relation between budget deficit and current account deficit in Turkey is analyzed for 2001Q2-2012Q2 period. According to the data obtained, budget deficit has negative and statistically meaningful effect on current account balance. On the other hand, budget deficit has negative effect on current account balance in short terms.

Keywords: Budget deficit, Current account deficit, Twin deficit, Co-integration analysis, ARDL model.

\section{$(\mathrm{cc}) \mathrm{EY}$}

New articles in this journal are licensed under a Creative Commons Attribution 3.0 United States License.

\section{ULLS

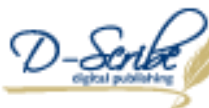

This journal is published by the University Library System of the University of Pittsburgh as part of its D-Scribe Digital Publishing Program, and is cosponsored by the University of Pittsburgh Press. 


\section{The Relationship between the Budget Deficit and Current Account Deficit in Turkey}

\author{
Dr. Seyfettin Erdoğan
}

Dr. Durmuş Çağrı Yıldırım

\section{Introduction}

The studies analyzing the relation between budget deficit and current account deficit focus on the validity of Keynesian view and Equivalence Hypothesis. In terms of Keynesian view, budget deficit affects current account deficit. In other words, there is a causality relation from budget deficit towards current account deficit. Positive relation between budget deficit and current account deficit is explained with twin deficits hypothesis. Unlike Keynesian view, Ricardian Equivalence Theory supports the idea that there is no relation between budget deficit and current account deficit.

There are numerous studies analyzing the direction and presence of the interaction between budget deficit and current account deficit. Some of the said studies obtained data that support Keynesian View and some of them obtained data that support Ricardian Equivalence Theory. The data from the said studies is leading for policy makers in terms of determining the quality of the policy to be preferred and the economic policy to be pursued.

In this study, the relation between budget deficit and current account deficit in Turkey is analyzed for 2001Q2-2012Q2 period. According to the data obtained, budget deficit has negative and statistically meaningful effect on current account balance. On the other hand, budget deficit has negative effect on current account balance in short terms.

This study includes two sections. In the first section, there is literature research and in the second section, there is empiric analyze.

\section{Literature Research}

There is consensus between some of the data obtained from the studies analyzing the relation between budget deficit and current account deficit. Some studies make twin deficit hypothesis valid and some of them have data on the contrary. Some studies used a single country data and some of them used data from multiple countries. The data from some of the studies in literature is as follows:

Arora and Dua (1993) researched about the effects of budget deficit on interest rates, investments and foreign trade. According to the data obtained, budget deficits exclude national investments and make foreign trade deficits grow bigger. Vamvoukas (1999) conducted research on the relation between budget deficit and foreign trade deficit for 1948 - 1994 periods. Obtained data showed that there is one way causality from budget deficit towards foreign trade deficit in both short and long terms. Khalid and Guan (1999) tested data from 5 different countries for 1952 - 1994 period and conducted research on the relation between budget deficit and current account deficit. Data obtained from this research did not support any long-run relationship between the two deficits for developed countries while the data for developing countries did not reject such a relationship. Results do not support any longrun relationship between the two deficits for developed countries while the data for developing countries do not reject such a relationship. Fidrmuc (2003), took samples from industrialized and developing country economies and tested the data related to $1970-2001$ period. Although there are differences between 1980s and 1990s, he got proofs related to the validity of twin deficit hypothesis in some countries. Pattichis (2004), used the data related to 1982 - 1997 term and analyzed the relation between budget deficit and foreign trade deficit in Lebanon. The results support the conventional Keynesian view. Saleh, Nair and Agalewatte (2005), used 1970 - 2003 data of Sri Lanka and conducted research on the benefits of financial spread on current account instability. The results support the Keynesian view. There is no long term relation between current account deficit and budget deficit. On the other hand, the direction of the causality is towards current account deficit from budget deficit. Onafowora and Owoye (2006) conducted research on the concept of twin deficit for Nigeria. The results showed there is positive relation between foreign trade deficit and budget deficit for both long and short terms. Salvatore (2006) tested the data of US, Japan, Germany, Britain, France, Italy and Canada for 1973 - 2005 periods. According to the results, there are strong proofs for direct relation between budget deficit and current account deficit. However, this relation shows itself as delayed. Chowdhury and Saleh (2007) tested the data for 1970 - 2005 period of Sri Lanka. The results support the conventional view. Kim and Roubini (2008) investigated the effects of budget deficit on current account deficit and real exchange rate by data of USA for the period between 1973 - 2004. In the short-run, budget deficit shocks improve the current account balance and lead to the depreciation of real exchange rate. Data is explained with"twin divergence" concept. Boileau and Normandin (2009) conducted research on the effect of tax shocks on budget deficit and foreign deficit by using data from 16 countries and for post 1975 era. The results Show that tax shocks lead budget deficit and foreign deficit to move in a positive way. Baharumshah, İsmail and Lau (2009), used 
data from five Association of Southeast Asian Nations (ASEAN) countries and tested the validity of twin deficit hypothesis. According to the results, in Malaysia, Thailand and Philippines, budget deficit plays an important role for determining current account deficit. According to the results, there is one way causality from current account balance towards budget balance. There is no data related to a causality from budget balance towards current account balance. Holmes (2011), used data from 1947 - 2009 period of USA and analyzed the relation between current balance and budget balance with threshold cointegration view. Results support the Keynesian view. Omoniyi, Olasunkanmi and Babatunde (2012) used data from 1970 2008 period and conducted research on twin deficit effects of Nigeria. Results Show that there is dual relation between budget deficit and foreign trade deficit. Ratha (2011), used data from India for 1998 - 2009 period and tested the validity of twin deficit theory. Kalou and Paleologou (2012) used $1960-2007$ period data in order to explain the casual effect between budget deficit and current account deficit. In the study, the results show that there is a positive relation between tow deficits and the direction of the causality is from current account towards budget deficit.

There are also studies from Turkey analyzing the validity of twin deficit hypothesis: Akbostanc1 and Tunç (2002) tested data from 1987 - 2001 period and conducted research on the relation between budget deficit and foreign trade deficit. Results support twin deficit hypothesis. Kurtlar and Şimşek (2001) tested data from 1984 - 2000 period. According to the results, conventional view is valid for both short and long terms. Günaydın (2004), used data from 1987 - 2003 period and conducted research on the casual relation between budget deficit and foreign trade deficit. According to the results, there is one way casual relation between budget deficit and foreign trade deficit. The direction of the causality is from budget deficit towards foreign trade deficit. Ümit and Yıldırım (2008) tested data from 1987 2005 period in three-month terms in order to research the validity of Twin Deficits Hypothesis for Turkey and used VAR method. Results show that Twin Deficits Hypothesis is also valid for Turkey. K1lavuz and Dumrul (2012) tested the relation between budget deficit and current account deficit in Turkey by using border test, VAR analysis and Granger Causality Test. In this study, the results show that there is no long term relation between current account deficit and budget deficit.

\section{Model and Data Set}

In the present study, the validity of the twin deficits hypothesis is tested. The data used to test the hypothesis were obtained from the websites of the Central Bank of the Turkish Republic, Treasury and IMF (IFS) as three-monthly data. The analysis period includes 2001Q2-2012Q2 depending on the availability of healthy data. Equation (1) is estimated to test the twin deficits hypothesis.

$$
C I D_{t}=\alpha_{0}+\alpha_{1} B U T C E+\alpha_{2} K U R+\alpha_{3} F A I Z+\mu_{t}
$$

where CID denotes the rate of Current Account Balance to GDP, BUTCE denotes the rate of consolidated budget balance to GDP, KUR is Real Exchange Rate, and Kur and Faiz denote the interest rate of government debt securities.

$\mu_{t}$ is error terms.

The existence of relationships among the series in Equation (1) will be investigated by means of cointegration analysis. However, the stationarity of the series is important regarding the investigation of relationships among the series. The analyses carried out with non-stationary series can cause the problem of spurious regression. Because of the spurious regression problem, the difference of series can be taken and series become stationary. However, the difference or taking their differences can cause loss of information.

Cointegration analysis is based on the assumption that longrun composition of non-stationary series can be stationary. Cointegration analysis can also measure the availability of long-run relationships among the series that are stationary at the same level and even the rate (speed) of moving towards equilibrium in case of a deviation with error correction model (Shittu, Yemitan and Yaya, 2012: 56). Peseran et al. (2001) developed an alternative test for the necessity of the series to be at the same level. Standard F statistic and $t$ statistic are used for the lag levels of the variables in this test. The basic hypothesis for the analysis is that there is no long-run relationship among the series. If the basic hypothesis is accepted, it is concluded that there is no relationship among the series regardless of the stationarity levels of the variables $(\mathrm{I}(0)$ or $\mathrm{I}(1)$ ) (Peseran et al. 2001: 298). The Peseran (2001) test has been used in this study since both level and difference stationary series can be analyzed together in the test developed by Peseran et al.

The test developed by Peseran et al. (2001) consists of two stages. During the first stage, it is investigated whether there is a long-run relationship among the series included in the analysis. If it is seen there is a long-run relationship among the series, in the second stage the structure of longand short-run relationships are examined. When investigating cointegration relationship in the analysis, the basic and alternative hypotheses used are (Akinlo, 2006: 447):

$$
\begin{aligned}
& H_{0}: \alpha_{4}=\alpha_{5}=\alpha_{6}=0 \\
& H_{1}: \alpha_{4} \neq \alpha_{5} \neq \alpha_{6} \neq 0
\end{aligned}
$$

In the test of Peseran et al. (2001), regardless of the stationarity situations of the variables $(\mathrm{I}(0)$ or $\mathrm{I}(1))$, it can be examined whether there is a relationship among the levels of the series. As a result of the analysis if $\mathrm{F}$ statistic (calculated value) drops out of the critical values, a definite result is reached. However, if $\mathrm{F}$ statistic falls between these 
limits, a definite result cannot be reached. In this case, the cointegration relationship among the series should be known for a definite result (Peseran et al., 2001: 289-290).

\section{Empirical Analysis}

Before investigating the relationships among the series, the stationarity of the series will be examined. The stationarity of the series are shown in Table 1.

Table 1: Unit Root Test Results for Level Values of the Series

\begin{tabular}{|c|c|c|c|c|}
\hline SERIES & & $\begin{array}{c}\text { ADF } \\
\text { test } \\
\text { statistics }\end{array}$ & $\begin{array}{c}\text { ADF } \\
\text { Critical } \\
\text { Value } \\
(1 \%)\end{array}$ & $\begin{array}{c}\text { ADF } \\
\text { Critical } \\
\text { Value } \\
(5 \%)\end{array}$ \\
\hline \multirow{3}{*}{ BUTCE } & None & -0.920 & -1.948 & -1.612 \\
\hline & Intercept & -4.585 & -3.571 & -2.922 \\
\hline & Trend\&Int & -4.674 & -4.156 & -3.504 \\
\hline \multirow{3}{*}{ CID } & None & -0.898 & -2.617 & -1.948 \\
\hline & Intercept & -2.031 & -3.584 & -2.928 \\
\hline & Trend\&Int & -4.544 & -4.175 & -3.513 \\
\hline \multirow{3}{*}{ KUR } & None & 0.251 & -2.613 & -1.947 \\
\hline & Intercept & -2.111 & -3.571 & -2.922 \\
\hline & Trend\&Int & -3.236 & -4.156 & -3.504 \\
\hline \multirow{3}{*}{ FAIZ } & None & -2.486 & -2.617 & -1.948 \\
\hline & Intercept & -5.552 & -3.592 & -2.603 \\
\hline & Trend\&Int & -4.654 & -4.198 & -3.523 \\
\hline \multirow{3}{*}{ DKUR } & None & -8.219 & -2.614 & -1.947 \\
\hline & Intercept & -8.175 & -3.574 & -2.923 \\
\hline & Trend\&Int & -8.102 & -4.161 & -3.506 \\
\hline
\end{tabular}

While evaluating the unit roots of the series, since all the series have constant and trend effects, the results with constant and trend are taken into consideration for the unit root analysis results. It is seen that all other series except for Kur series are level stationary. Because Kur series was not level stationary, its first difference was taken and unit root test was applied again. It was seen that the first difference of Kur series was stationary.

After investigating the stationarity of the series, cointegration relationship among the series can be examined. Because the stationarity levels of the series are different, ARDL test will be used. During the first stage of the test, in order to investigate the relationships among the series, F statistics obtained from Equation (1) and critical values of Peseran et al (2001) are compared. The results are indicated in Table 2.
Table 2: Limit Test

\begin{tabular}{|lccc|}
\hline k & F statistic & Lower Limit* & Upper Limit* \\
\hline \hline 4 & 18.387 & 3.47 & 4.57 \\
\hline
\end{tabular}

*Peseran et al. (2001) Critical Values were selected for a significance level of $5 \%$.

It is concluded that there is a co-integration relationship among the series since the F-statistic value obtained from Equation (1) exceeds the upper limit of the value in the table of Peseran et al. Therefore, short- and long-run relationships can be examined now.

\section{Long-Run Relationship}

After it is found out that there is a long-run co-integration relationship among the series, the model in Equation (2) has been estimated to investigate the long-run relationship among the series.

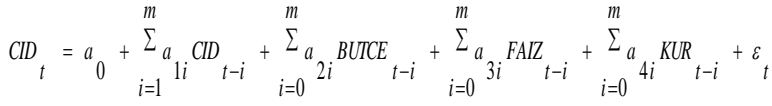

Schwarz criterion has been taken into account to select appropriate lag lengths for the estimation of the Equation (2). The most suitable ARDL model for the criterion selected has been determined as ARDL $(0,0,0,0)$. The results obtained from the model are indicated in Table 3.

Table 3: Results of Long-Run Relationships

\begin{tabular}{|c|c|c|c|}
\hline Variables & Coefficient & t-Statistic & Prob. \\
\hline \hline BUDGET & $\mathbf{- 0 . 2 4 6}$ & $\mathbf{- 2 . 9 9 0}$ & $\mathbf{0 . 0 0 4}$ \\
\hline INTEREST & $\mathbf{0 . 0 0 1}$ & $\mathbf{3 . 5 3 3}$ & $\mathbf{0 . 0 0 1}$ \\
\hline $\boldsymbol{R A T E}$ & $\mathbf{- 0 . 0 0 1}$ & $\mathbf{- 1 2 . 9 9 6}$ & $\mathbf{0 . 0 0 0}$ \\
\hline $\begin{array}{c}\text { R-squared } \\
\text { Adjusted R- } \\
\text { squared }\end{array}$ & 0.571 & $\begin{array}{c}\text { Durbin-Watson } \\
\text { stat }\end{array}$ & 1.116 \\
\hline
\end{tabular}

When long-run coefficients are considered in Table 3 , it is concluded that budget deficit has a negative effect on current account balance. 


\section{Short-Run Relationship}

After studying long-run relationships among series, shortrun relationships can be examined now. Equation (3) will be used to examine short-run relationships.

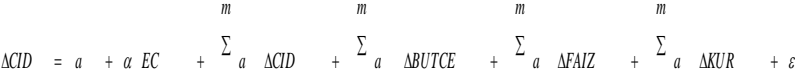

$$
\begin{aligned}
& 1 t-1 \\
& 1
\end{aligned}
$$

balance. According to this situation, we need to avoid policy applications that have the risk of increasing budget deficit. In calm periods, increasing public expenses may be an option. However, when we see that public expenses may increase budget deficit, we should be cautious about implementing expanding fiscal policy.

\section{REFERENCES}

Akbostanc1, Elif ve Gül İ. Tunç (2002). “Turkish Twin Deficits: An Error Correction Model of Trade Balance". ERC Working Papers.

Table 4 Results of Short-Run Relationships

\begin{tabular}{|c|c|c|c|}
\hline Variables & Coefficient & t-Statistic & Prob. \\
\hline ECM(-1) & $\mathbf{- 0 . 5 4 0}$ & $\mathbf{- 3 . 7 4 8}$ & $\mathbf{0 . 0 0 0}$ \\
\hline DBUDGET & $\mathbf{- 0 . 1 7 6}$ & $\mathbf{- 2 . 6 8 6}$ & $\mathbf{0 . 0 1 0}$ \\
\hline DINTEREST & $\mathbf{0 . 0 0 0}$ & $\mathbf{0 . 8 0 1}$ & $\mathbf{0 . 4 2 7}$ \\
\hline DRATE & $\mathbf{- 0 . 0 0 1}$ & $\mathbf{- 0 . 9 5 9}$ & $\mathbf{0 . 3 4 2}$ \\
\hline R-squared & 0.317 & $\begin{array}{c}\text { Durbin-Watson } \\
\text { stat }\end{array}$ & 1.873 \\
\hline $\begin{array}{c}\text { Adjusted R- } \\
\text { squared }\end{array}$ & 0.268 & & \\
\hline \multicolumn{2}{|c|}{} & & \\
\hline
\end{tabular}

According to the results of the error correction mechanism in Table 4 estimated to measure the time short term deviation among the series moves towards equilibrium, adjustment coefficient is seen to be -0.55 . The adjustment coefficient, which is the coefficient of error term, is negatively marked and statistically significant. It is concluded that a disequilibrium among the series is eliminated after 1,8 periods.

\section{CONCLUSION}

In this study, quarterly data from 2001Q2-2012Q2 period is used in order to test twin deficit hypothesis in Turkey by using border test approach. In empirical analysis, firstly, coentegration relation is detected between series. After that, long term relations are researched and results show that budget deficit has negative effect on current account deficit in long term and this effect is statistically meaningful. When short terms relations are researched, there is instability between series but this instability disappears in short term. On the other hand, budget deficit has negative effect on current account balance in short term.

Current account deficit is an indicator in terms of macro-economic performance and expectations. Expanding current account deficit effects expectations in a negative way and increase the financial crisis risk. This study shows that budget deficit has negative effect on current account
Akinlo, A. Enisan (2006), "The stability of money demand in Nigeria: An autoregressive distributed lag approach", Journal of Policy Modeling, 28 445452.

Arora, Harjit K and Pami Dua (1993). "Budget Deficits, Domestic Investment and Trade Deficits". Contemporary Economic Policy. 11, (1), 29 - 44.

Baharumshah, Ahmad Zubaidi, Hamizun İsmail and Evan Lau (2009). "Twin Deficits Hypothesis and Capital Mobility: The ASEAN-5 Perspective”. Jurnal Pengurusan.29, 15-32.

Boileau Martin and Michel Normandin (2009). "Do Tax Cuts Generate Twin Deficits? A Multi-Country Analysis”. DEFI Working Paper. No.2009-5. 
Chowdhury, K. and Saleh. A.S. (2007). Testing the Keynesian Proposition of Twin Deficits in the Presence of Trade Liberalisation: Evidence from Sri Lanka. University of Wollongong Economics Working Paper Series. WP 07-09, 1-33.

Fidrmuc, Jarko (2003). “The Feldstein-Horioka Puzzle and Twin Deficits in Selected Countries". Economics of Planning. 36, 135- 52.

Günaydın, İhsan (2004). "The Relationship Between Budget and Trade Deficits: Turkey)". Ekonomik Yaklaşım. 15, (52-53), 143 - 60.

Holmes, Mark J. (2011) "Threshold cointegration and the short-run dynamics of twin deficit behaviour". Research in Economics. 65, 271 - 77.

Kalou, Sofia and Suzanna-Maria Paleologou (2012). "The twin deficits hypothesis: Revisiting an EMU country". Journal of Policy Modeling. 34, $230-$ 41.

Katırcioglu, Salih Turan, Sami Fethi and Meryem Duygun Fethi (2009). “Twin deficits phenomenon in small islands: an empirical investigation by panel data analysis”. Applied Economics Letters. 16, 1569 73.
Khalid, Ahmed M. and Teo Wee Guan (1999). "Causality tests of budget and current account deficits: Cross-country comparisons". Empirical Economics. 24, 389- 402.

K1lavuz, Emine and Yasemin Dumrul (2012). "The validity of Twin Deficits Hypothesis: Theory and Practice”. Atatürk University, The Journal of Faculty of Economics and Administrative Sciences. 26, (3 - 4), 239 - 58.

Kim, S. and Roubini. N. (2008)." Twin deficit or twin divergence? Fiscal policy current account and real exchange rate in the U.S.”. Journal of International Economics. 74, $362-93$.

Kutlar, A. and Şimşek. M. (2001). An Econometric Analysis of the Effects of Budget Deficits on Trade Deficits in Turkey: 1984 (4) - 2000(2)”. Dokuz Eylül University, The Journal of Faculty of Economics and Administrative Sciences. 16 (1), 1- 13 .

Omoniyi, Oladipo Samuel, Oseni Isiaq Olasunkanmi, Onakoya Adegbemi Babatunde (2012). “Empirical Analysis of Twins' Deficits in Nigeria”. IJMBS. 2, (3), 38 - 41. 
Onafowora, Olugbenga A. and Oluwole Owoye (2006).

“An Empirical Investigation of Budget and Trade

Deficits: The Case of Nigeria". The Journal of Developing Areas. 153 - 74.

Pattichis, Charalambos (2004). "Budget and trade deficits in Lebanon". Applied Economics Letters. 11, 105-108.

Peseran, M. Hashem, Yongcheol Shin ve Richard J. Smith (2001), "Bounds Testing Approaches to the Analysis of Level Relationships", Journal of Applied Econometrics, Vol. 16, 3, ss. 289- 32.

Ratha, Artatrana (2011), "Twin Deficits or Distant Cousins? Evidence from India". Economics Faculty Working Papers. Paper 5.

Saleh, Ali Salman, Mahendhiran Nair and Tikiri Agalewatte (2005). The Twin Deficits Problem in Sri Lanka: An Econometric Analysis. South Asia Economic Journal. 6, 221 - 39.
Salvatore, D. (2006). Twin deficits in the G-7 countries and global structural imbalances". Journal of Policy Modeling. 28, $701-12$.

Shittu, Olanrewaju I., Raphael A. Yemitan ve OlaOluwa S. Yaya (2012), “On Autoregressive Distributed Lag, Cointegration And Error Correction Model", Australian Journal of Business and Management Research, Vol.2 No.08 pp:56-62

Ümit, A.Öznur and Kemal Yıldırım (2008). "Twin Deficits Hypothesis". İktisat İşletme ve Finans. 23, (267), $116-32$.

Vamvoukas, G. A. (1999). The Twin Deficits Phenomenon: Evidence from Greece. Applied Economics. 31, 1093-1100. 